\title{
Book Review of \\ Congress, E.P., Takooshian, H. , \& Asper, A. (Eds.). (2020). Behavioral Science in the Global Arena. Vol. 1. Addressing Timely Issues at the United Nations and Beyond. Charlotte NC: Information Age Publishing
}

\author{
Roswith Roth \\ University of Graz \\ 3 Universitaetsplatz, Graz, 8010, Republic of Austria
}

This book tells many stories about Behavioral Sciences at the United Nations (UN). It gives insights in important issues of the UN's 17 "Sustainable Developmental Goals (SDGs)" (United Nations General Assembly, 2015) and how behavioral science contributes to these goals. It addresses different readers in various contexts, professionals and students. It is an excellent and exorbitant educational textbook for students and interested readers who want to know more about the projects and accomplishments of the UN.

The editors are three UN representatives, most of the chapters are authored by a leading expert in that specialty, together with a student intern working with the $\mathrm{UN}$, so a profound insight of $\mathrm{UN}$ issues is provided.

The book contains 16 chapters, divided in five sections. Each chapter follows a common format: an overview of its timely issue, individual and com-

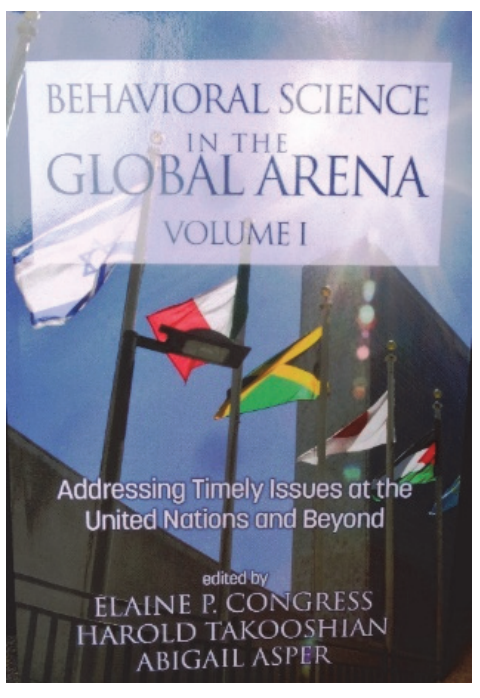
munity interventions and the contribution of global interventions based on treaties, recommendations and the SDGs of the UN, a glossary of key concepts, study questions, and a list of references.

A doyen of psychology and representative of the UN in NY Florence Denmark wrote the foreword and the editors Harold Tokooshian and Elaine P. Congress gave in the preface an overview about the Behavioral Sciences at the UN. The UN was formed June 26, 1945 by 51 nations in San Francisco, and has since 1947 his headquarters in New York. The structure of the UN is a composition of three parts: governments, agencies, like the World Health Organization (WHO), 
International Labor Organization (ILO), United Nations International Children's Emergency Fund (UNICEF), International Monetary Fund (IMF) and "civil society", means volunteer experts to actively support the UN agenda. This includes non-governmental organizations (NGOs). Much of the work of NGOs is done through the standing committees of the commissions on NGO (CoNGO). Since 2015, the attention of the UN and its NGOs has focused on the 17 SDGs for year 2030 an issue permeating all UN goals.

Section $\boldsymbol{A}$ "Serving Current Populations" deals with the challenges of aging people, children, migrants and gender equality in four chapters.

Global aging, gender differences in aged, ageism (age discrimination) and physical and mental health of elderly people, like dementia are important matters. Multilevel interventions were provided at the governmental level documented in the MIPAA (Madrid International Plan of Action on Aging) but like some of the UN forward-looking plans, even if the governments sign, the plan was "not-binding".

Child welfare and well-being of the world's 2.3 billion children below the age of 18 , focusing especially on low-and-lower-middle-income countries are discussed. UNICEF is custodian or co-custodian for 17 SDG global indicators related to children. Selectively the progress for SDG targets concerned with poverty, under-five mortality, education and child marriage are dealt with in this chapter, it gives also a list of international organizations promoting children.

In 2017, there were approximately 258 million migrants around the world, an increase of almost 50\% since the turn of the millennium. It is vital that we understand how to thrive within cultures other than that of our country of origin and promote the integration of migrants wherever they settle.

Despite progress made toward gender equity around the world, gender disparities in political power, economic opportunity, education, and health persist. The status of gender equity through the lenses of reproductive rights and reproductive justice, including the intersectionality of gender issues, behavioral research on gender-based discrimination, and the progress of interventions at the United Nations, at the community and individual levels are presented.

Section B “Upholding Social Justice” contains four chapters about poverty and inequality, social protection, freedom and democracy and human rights.

In 2015, poverty has affected 736 million people around the world. 22,000 people die every day due to poverty-related causes. Poverty is a global problem and number 1 of the SDGs. It is important to understand how poverty is defined and how poverty can be eliminated or reduced. This chapter reviews the different types of poverty, challenges impacted by poverty due to inequality and lack of poverty measures.

Social protection has been an important element of intergovernmental policy discourse at the UN aimed at finding an appropriate response to major challenges of poverty, vulnerability and exclusion that many countries are striving.

Democracy offers freedom of expression and action, human rights protections, access to diverse sources of information, political inclusion and social equality, government responsiveness and transparency, economic growth, and sustained peace. Freedom and democracy can appear differently in countries where they are situated and are determined contextually by cultural norms, economic systems (free-market, centrally planned), geography, national history, and class structure. 
The Universal Declaration of Human Rights (United Nations General Assembly, 1948) asserts that democracy reflects a basic human right for self-determination and full participation in all aspects of living.

Human rights are core to the United Nations system and embodied in the Charter of the UN that was adopted by the General Assembly in 1945. Human rights laws applying to all individuals throughout the world and encompass specific standards for women, children, persons with disabilities, minorities and other vulnerable groups to protect them from discrimination. The mechanisms established by UN to promote and protect these rights and to assist states in carrying out their responsibilities are presented.

Section C "Promoting Harmony" contains two moving and important chapters about Counter Terrorism and Crime Prevention and Control.

Terrorism is arguably the most dangerous phenomenon facing the world in the $21^{\text {st }}$ century and may be the biggest challenge to be addressed. There are more terrorist groups today than ever before, and they are more extreme and brutal. Groups such as Taliban and al-Qaeda in Afghanistan, ISIL/ISIS in Iraq, AL-Nusra Front in Syria, Al-Shabab in Somalia, and Boko Haram in Nigeria remain a serious threat. Steps the UN, state governments, and civil society can take to counteract the growing number of organized terrorist groups, the rise of lone wolves, and curtail radicalization and how behavioral science contributes to the war on terrorism are examined.

The total reported crime in the world has steadily increased from 2,300 incidents per 100,000 people in 1980 to over 3,000 in 2000. Many SDGs directly relate to the mission of crime prevention and control. One example, SDG 5 is gender equity, which is important for crime prevention and control to ensure women and girls are protected and safe in their communities.

Section D “Improving Human Health" contains three chapters, dealing with mental health, physical health and disasters and trauma interventions.

While mental health disorders constitute $14 \%$ of global illness worldwide, almost three quarters of this burden occurs in lower income countries, where a shortage of trained personnel and other resources leave enormous populations with little or no access to mental illness treatment. WHO's Global Mental Health Action Plan, adopted in 2013 by all 194 member states, has been a major step in recognizing formally the importance of mental health, and pushing forward the agenda of suicide prevention globally (World Health Organization, 2013).

Physical health was first defined as a central component of the Right to Health, which was further codified as a human right in the 25th Article of the 1948 Universal Declaration of Human Rights. The physical health encompassed under the UN framework, as well as global efforts by the UN, with an emphasis on the UN SDGs, to improve the human condition as it relates to physical health (UN General Assembly, 2015) are focused on.

The impact of natural or human-made disasters on life, property and livelihood are highly disruptive and can result in permanent changes. Disaster preparedness becomes much more imperative as the frequency of disasters and their effects are increasing yearly. Disaster risk management can be used to refer to both risk reduction (prevention, preparedness and mitigation) and humanitarian action (response, relief and reconstruction). The work of NGOs, and the UN, is to complement government efforts in bringing rapid relief to those affected. 
Section E "Supporting Environmental Health" includes two chapters "Promoting Environmental Health: Challenges and Successes", "Reducing Urban Noise" and a conclusion (by the editors).

Promoting environmental health is a major focus for all concerned about the future of our world. The unmet needs of humanity as identified in the SDGs are health, food, water, income, gender equality, social equity, energy, jobs, voice, resilience, and education, and these goals are to reach: climate change, freshwater use, nitrogen and phosphate cycles, ocean acidification, chemical pollution, atmospheric aerosol loadings, ozone depletion, biodiversity loss, and land use change.

Many studies have linked noise to cardiovascular disorders, learning deficits and a diminished quality of life. Looking at how noise is linked to disease could be used to explain why noise may be identified as a menace. The burden of disease is calculated, in a single measure of disability-adjusted life-years (DALYs), as the sum of the years of life lost from premature mortality and the years lived with disability for people living with the disease or health condition or its consequences in the general population.

Conclusion: "This is the best of times, but also the worst of times" (Dickens, 1859) for the 7.7 billion people who live in our world today (World Population, 2020) is the resume of the editors - and it represents the view we see the world today - including the insecure times of COVID-19 and the efforts to build a "new normal".

Congratulation to the editors and contributors of this book. We are looking forward to the continuation of this informative, enlightening and instructive book series.

\section{References}

Dickens, Ch. (1859). A Tale of Two Cities. In C. Dickens (Ed.), All the Year Round. A Weekly Journal. London: Chapman \& Hall.

United Nations General Assembly. (1948). Universal declaration of human rights. GA resolution 217A. https://www.un.org/en/universal-declaration-human-rights/

United Nations General Assembly. (2015). Transforming Our World: The 2030 Agenda for Sustainable Development. Retrieved from https://sustainabledevelopment.un.org/post2015/transformingourworld/publication

World Health Organization. (2013). Comprehensive Mental Health Action Plan 2013-2020. Geneva: World Health Organization. Retrieved from http://apps.who.int/gb/ebwha/pdf_files/WHA66/A66_R8-en.pdf

World Population. (2020). Current World Population. Retrieved from: https:/www.worldometers.info/ world-population/\#: :text=7.8\%20Billion\%20(2020),Nations\%20estimates\%20elaborated $\% 20$ by $\% 20$ Worldometer

\section{Article history:}

Received: 7 July 2020

Revised: 20 July 2020

Accepted: 15 September 2020

\section{For citation:}

Roth, R. (2020). Book Review of Congress, E.P., Takooshian, H., \& Asper, A. (Eds.). (2020). Behavioral Science in the Global Arena. Vol. 1.Addressing Timely Issues at the United Nations and Beyond. Charlotte NC: Information Age Publishing. RUDN Journal of Psychology and Pedagogics, 17(4), 759-763. http://dx.doi.org/10.22363/2313-16832020-17-4-759-763 
Bio note:

Roswith Roth, Ph.D., is a University Professor ret. at the University of Graz (Graz, Austria). She is a licensed clinical and health psychologist and psychotherapist. Since $1983-$ member of the International Council of Psychologists and area chair of Austria, she edited 10 Proceedings of the Annual Conventions of ICP. During 2000-2001, she was President of ICP and she is representative of ICP at the UN in Vienna since 1994. From 2010 to 2012 she was chair of the NGO Committee on the Family and since 2012 she is member of the NGO Committee on the Status of Women. Website: https://homepage.unigraz.at/roswith.roth/.E-mail: roswith.roth@uni-graz.at

DOI 10.22363/2313-1683-2020-17-4-759-763

Рецензия на книгу

\title{
Рецензия на книгу: \\ Behavioral Science in the Global Arena. Vol. 1. Addressing Timely Issues at the United Nations and Beyond / ed. by E.P. Congress, H. Takooshian, A. Asper. Charlotte NC: Information Age Publishing, 2020. 238 p.
}

\author{
P. Pot \\ Университет Граца \\ Австрийская Республика, 8010, Граи, Universitaetsplatz, 3
}

\section{История статьи:}

Поступила в редакцию: 7 июля 2020 г.

Принята к печати: 15 сентября 2020 г.

\section{Для цитирования:}

Roth R. Book Review of Congress, E.P., Takooshian, H., \& Asper, A. (Eds.). (2020). Behavioral Science in the Global Arena. Vol. 1. Addressing Timely Issues at the United Nations and Beyond. Charlotte NC: Information Age Publishing // Вестник Российского университета дружбы народов. Серия: Психология и педагогика. 2020. Т. 17. № 4. C. 759-763. http://dx.doi.org/10.22363/2313-1683-2020-17-4-759-763

\section{Сведения об авторе:}

Pom Poсвит, Ph.D., профессор в отставке Университета Граца (Грац, Австрия), лицензированный клинический психолог и психотерапевт. С 1983 г. является членом Международного совета психологов (International Council of Psychologists, ICP), главой регионального представительства ICP в Австрии, редактором 10 сборников материалов ежегодных съездов ICР. В 2000-2001 гг. была президентом ICР, с 1994 г. является представителем ICP при ООН в Вене. С 2010 по 2012 г. возглавляла негосударственный Комитет по вопросам семьи, в настоящее время член негосударственного Комитета по положению женщин. Вебсайт: https://homepage.uni-graz.at/roswith.roth/. E-mail: roswith.roth@uni-graz.at 